\title{
Simulation evaluation of groundwater resources in southeastern Bosten Lake based on GMS
}

\author{
Shi Qiang, ${ }^{1, *}$ Yan Changhong ${ }^{1}$, and Yu Peng ${ }^{1}$ \\ ${ }^{1}$ North-West Institute of Nuclear Technology, Xi'an, 710024, Shaanxi, China
}

\begin{abstract}
Bosten Lake is located in Yanqi Basin of Xinjiang. A working area in the southeast of China is influenced by the regulation of Bosten Lake, and the transitional zone of climate in the north and south of Xinjiang, forming a climate of large evaporation, dry and little rain, and groundwater is a very important fresh water resource. In order to find out the composition of groundwater resources in the working area, the groundwater steady flow model is established by using the data of borehole, well, pumping test and so on, and the groundwater resources in this area are evaluated. The groundwater exploitation mode in the simulated area is evaluated. The results show that: the exploitable groundwater resources in the simulated area is about 22.045 million $\mathrm{m}^{3} / \mathrm{a}$. Changing the mode of agricultural water use under the existing groundwater equilibrium condition can effectively reduce the waste of groundwater resources.
\end{abstract}

\section{Introduction}

With the development of industry and agriculture and the improvement of people's living standard, the demand for water resources is rapidly expanding. Excessive exploitation of groundwater has led to many geological environmental problems. Numerical simulation of groundwater is a common method to predict and evaluate groundwater resources. It is necessary for people to reveal the laws of hydrogeology and evaluate and manage groundwater resources by establishing reasonable numerical models [1].

GMS is a commonly used groundwater simulation software, which can be used to simulate all flow and solute transfer problems associated with groundwater [2]. Compared with other similar software such as MODFLOW and so on, the function of each module of GMS software is more perfect, at the same time, it has good use interface and 3D visual effect, so it has become the most popular groundwater simulation software in the world.

Based on the groundwater exploration project in the southeastern part of Bosten Lake, a series of parameters are obtained by collecting historical data of geological and hydrogeological work carried out in the early period, field investigation and pumping test. The stable flow model of southeastern region of Bosten Lake was established by GMS, and the groundwater balance was calculated during the simulation period [3]. The model can basically reflect the distribution and movement law of groundwater in the study area and provide scientific basis for the development and management of groundwater resources in this area.

\section{Physical geography overview}

\subsection{Geographic and geomorphic}

The simulation area is located on the southeastern shore of Bosten Lake in the southeastern part of the Yanqi Basin, as shown in the figure. The northern part of the Bosten Lake area is a rushing alluvial fine soil plain, and the surface is silty sand, silt, silty clay deposited by the lake, and the terrain is gentle. The rolling aeolian dunes develop on both sides of the east and west; the central landform is the sloping plain of the piedmont flood Gobi. The surface is the sand gravel, spall and sandy soil of the alluvial deposit. The terrain is relatively flat. The southern landform is a piedmont residue high-goal platform with a severe cut. It is a northwest-southeast trend. It consists of a semi-cemented diluvium with a large relief.

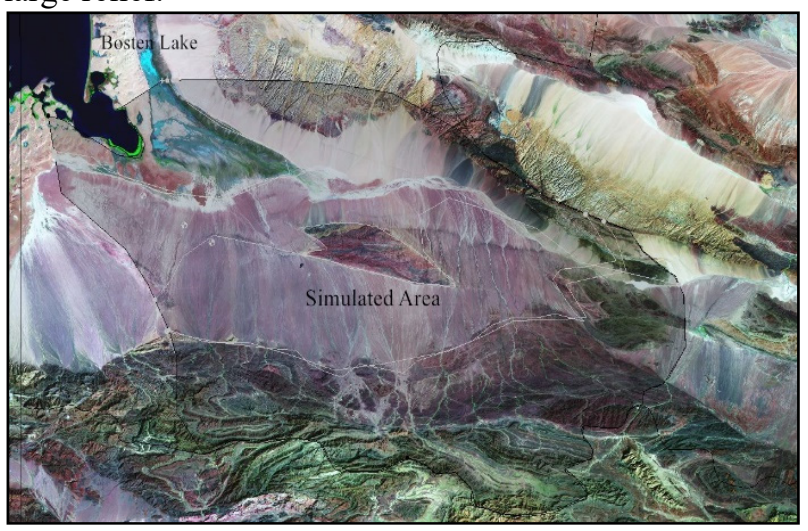

Fig. 1. Simulated area remote sensing image map

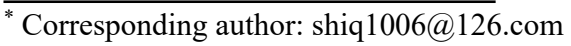




\subsection{Geological and hydrogeological overview}

The simulation area is deeply inland in Central Asia and is located in the transitional zone between the north and the south of Xinjiang. The temperature changes greatly, there is a great disparity between winter and summer, the rainfall is scarce, the evaporation is large, it is dry and windy, and it is the typical continental climate. There is no perennial surface water flow in the simulation area, and only some dry gullies will form a valley flood after the summer rainstorm. The Bosten Lake in the north is an inland freshwater lake with perennial stagnant water all year round. There are sporadic spring flows in the southern mountainous areas, which usually seep underground not far from surface runoff. Some of the dry gullies developed in the area are comb-like and braided, and there is only water flow when summer comes.

The strata in the simulated area are mainly Quaternary sediments, in the western and southern regions are the middle Pleistocene flood deposits, and in the middle and southeast of the simulation areas, they are upper Pleistocene-new series flood deposits, which form the Piedmont flood Gobi sloping plain. Near the coast of Bosten Lake, there is a holocene aeolian accumulation, which forms sand dune and sand mountain distributed along the shore of the lake. The depressions around Bosten Lake in the northern part of the simulation area are the holocene lacustrine deposit, forming wet swamps.

The simulated area is located at the edge of the Quaternary submersible basin. The loose deposits provide the space for the storage and migration of groundwater and form the pore water of the Quaternary loose rock. Due to the lack of perennial surface water flow, the groundwater recharge source is very poor. The main groundwater recharge is precipitation infiltration and summer flood flow infiltration recharge. Drainage mainly includes artificial mining, lateral horizontal runoff outflow and phreatic evaporation discharge.

\section{Regional hydrogeological conceptual model}

\subsection{Geological structure model}

The terrain of the simulated area is generally high in the south and low in the north, with outcrops in the south and west, the Quaternary sedimentary strata in the middle, and the lake region in the northern boundary. Many hydrogeological surveys have been carried out in the simulation area, but due to the loss of the old data, errors, unexposed aquifer drilling, serious contradiction of adjacent borehole data, drilling outside the simulated area, and so on, a large number of culling and comparison work has been carried out during the modeling process. The suitable borehole data have been selected repeatedly, combined with the regional hydrogeological report of 1:200,000, and finally 21 borehole data are applied to the model. The geological structure model is established as shown in Fig. 2. The model can easily view the geological structure of the study area and view any stratigraphic spatial distribution and geological profile from any angle.

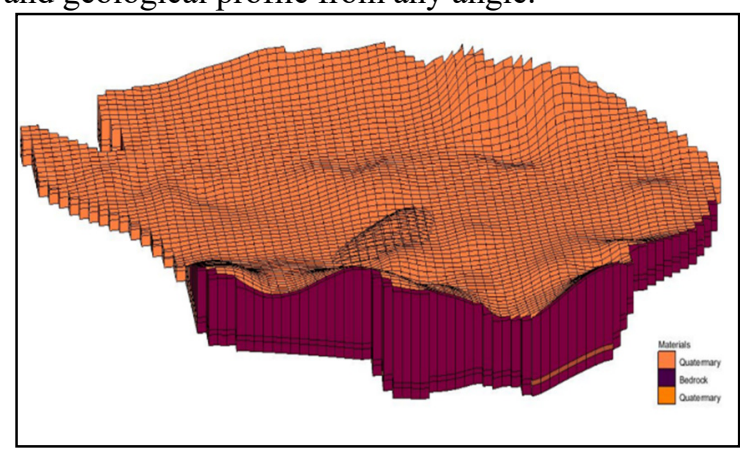

Fig. 2. Simulation area geological model

\subsection{Boundary condition generalization}

The study area is divided into boundaries, and the horizontal upper boundary includes the flow boundary and the water head boundary. According to the characteristics of groundwater runoff, the north boundary of phreatic aquifer is the surface of Bosten Lake, which can be generalized as the boundary of fixed head. The east and west sides of the study area are defined by the surface water and groundwater watershed as zero flow boundary, and the south is bounded by the ridge line watershed of outcropped mountains, which is the zero flux boundary, ie the water separation boundary. The model is about $60 \mathrm{~km}$ from north to south and $97 \mathrm{~km}$ from east to west, with a total area of $5820 \mathrm{~km}^{2}$.

The water-bearing strata in the vertical simulated area are mainly Quaternary loose layer, which can be generalized into two layers. The first layer is the main phreatic aquifer, the second is the confined aquifer, and the lower boundary is the bedrock bottom. The phreatic aquifer is mainly composed of sand gravel and gravel. The stratum contains less mud and most of them are loosely deposited state. The stratum porosity is large and the water permeability is good. The confined aquifer is composed of sand and gravel sand of the Middle Pleistocene sandy gravel sand, and some of the layers are also covered with gravels. The stratum porosity is large. The generalizable boundary conditions are shown in Fig. 3.

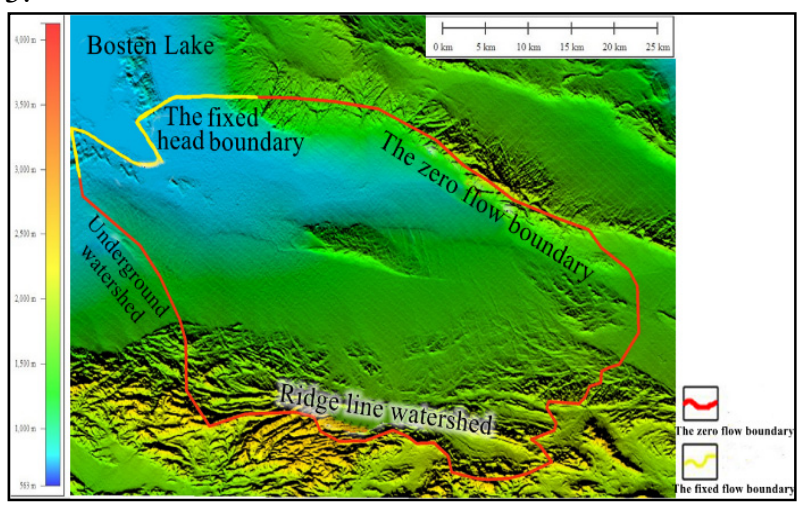

Fig. 3. Model range and boundary type

\subsection{Treatment of source and sink items}


Because the study area is located in arid area, the main source of recharge is precipitation and summer flood infiltration recharge. Groundwater exploitation and evaporation are the main discharge modes of groundwater.

The precipitation infiltration recharge amount is treated as the model surface recharge rate [4] (Recharge module). According to the historical precipitation data, the average annual precipitation in the simulated area is in accordance with the vertical zonation of the climate, and the precipitation increases with the increase of the topography, but not in a straight line. According to the data and the factors of altitude and topography, the direct recharge area of atmospheric precipitation in the study area is divided into three parts.

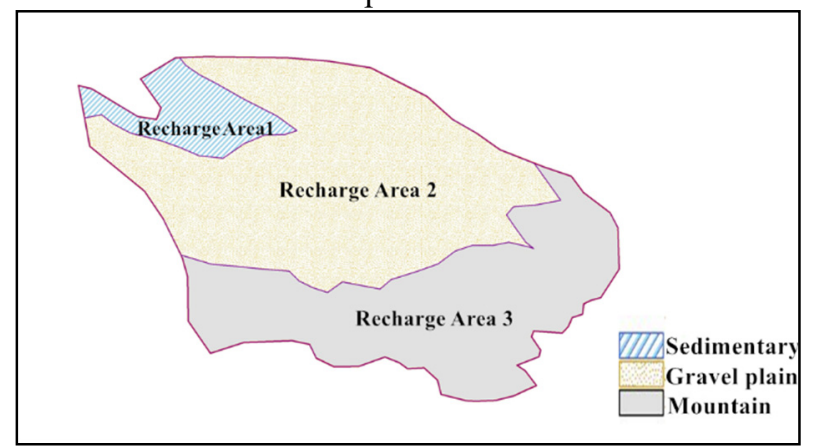

Fig. 4. Model range and boundary type

According to the hydrogeological report [3], the precipitation in summer accounts for about $80 \%$ of the annual precipitation in the region. It can be considered that the rest of the time precipitation is consumed by evaporation, which has no practical significance for groundwater recharge [5]. In this paper, $80 \%$ of the annual precipitation is chosen as the effective recharge source when calculating the direct infiltration recharge of atmospheric precipitation.

Considering terrain factor, lithologic structure, vegetation, geomorphology and so on, the range of infiltration and recharge coefficient $\alpha$ is $0.10 \sim 0.15$. Because the recharge zone 2 and the recharge zone 3 are basically gravel, spall and sandy soil, therefore the coefficient of infiltration and recharge $\alpha$ is 0.15 [6]. In the first part of the recharge area, there is sedimentary coverage, and the evaporation intensity is slightly higher than that in the northern mountainous area. Therefore, the coefficient of infiltration and recharge $\alpha$ is 0.12 .

Table 1. Calculation table of direct infiltration replenishment of atmospheric precipitation in the study area

\begin{tabular}{|c|c|c|c|}
\hline $\begin{array}{c}\text { Calculation } \\
\text { area }\end{array}$ & $\begin{array}{c}\text { Average } \\
\text { annual } \\
\text { effective } \\
\text { precipitation } \\
\mathrm{X}(\mathrm{mm} / \mathrm{a})\end{array}$ & $\begin{array}{c}\text { Infiltration } \\
\text { recharge } \\
\text { coefficient } \\
(\alpha)\end{array}$ & $\begin{array}{c}\text { Precipitation } \\
\text { direct } \\
\text { infiltration } \\
\text { recharge } \\
\text { rate(m/d) }\end{array}$ \\
\hline $\begin{array}{c}\text { Southern } \\
\text { mountains }\end{array}$ & 130 & 0.15 & 0.000043 \\
\hline $\begin{array}{c}\text { Central } \\
\text { gravel plain }\end{array}$ & 95 & 0.15 & 0.000031 \\
\hline $\begin{array}{c}\text { Northern } \\
\text { lacustrine } \\
\text { deposit }\end{array}$ & 85 & 0.12 & 0.000028 \\
\hline
\end{tabular}

Rainfall infiltration calculation formula
$\mathrm{Q}=1000 \cdot \alpha \cdot \mathrm{X} \cdot \mathrm{F}\left(\mathrm{X}=0.8^{*}\right.$ Actual annual precipitation $)$

The flood infiltration amount is treated as regional surface infiltration. According to the formula $\mathrm{Q}_{\text {flood }}=$ $1000 \mathrm{~F} \cdot \mathrm{A} \cdot \mathrm{n} \cdot \beta, \mathrm{n}$ is surface runoff coefficient, $\beta$ is flood leakage coefficient [7]. Combined with the hydrogeological report, the flood is formed once a year, and the average precipitation of the torrent is $13 \mathrm{~mm}$. The empirical value of surface runoff coefficient is 0.5 and the linear leakage coefficient is $67.9 \%$. The calculation results show that the recharge rate of flood flow is $0.000012 \mathrm{~m} / \mathrm{d}$.

The amount of manual extraction is controlled by well flow. According to the extraction statistics, according to the location of pumping wells obtained by remote sensing interpretation images, and according to the hydrogeological survey report, statistics of actual pumping wells' working conditions, the model pumping capacity is $-680 \mathrm{~m}^{3} / \mathrm{d},-1500 \mathrm{~m}^{3} / \mathrm{d},-2000 \mathrm{~m}^{3} / \mathrm{d}$ respectively. Input with three point wells.

Evaporation is fed into the model using negative surface recharge. According to the hydrogeological conditions of the study area, and the monthly average temperature data of the study area, the empirical formula of Lei Zhidong is selected according to the literature[8]:E $=\operatorname{Emax}\left(1-\mathrm{e}^{-\eta \mathrm{E} 0 / \mathrm{Emax}}\right), \quad$ The evaporation capacity is related to the soil quality and the buried depth of the groundwater level.

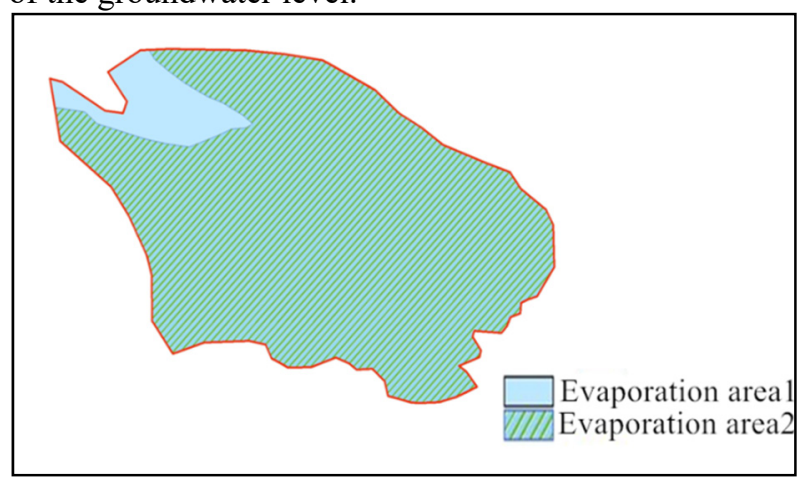

Fig. 5. Evaporation zone partition map

According to the field geomorphology investigation and the high precision remote sensing map of the study area, the topographic and geomorphologic interpretation, the soil quality of the evaporation area is calculated as sandy loam soil, the $E_{\max }$ is the limit evaporation intensity of the phreatic water under the condition of $\mathrm{H}$ buried depth, and the depth of phreatic evaporation is taken as $3 \mathrm{~m}$. Since the depth of diving in the northern region is very shallow, the evaporation area is divided in the figure, the evaporation intensity blue area is 0.00005 $\mathrm{m} / \mathrm{d}$, and the green area is $0.000003 \mathrm{~m} / \mathrm{d}$.

\subsection{Hydrogeological parameter}

The hydrogeological parameters involved in the model mainly include horizontal permeability coefficient and vertical permeability ratio. The partition of horizontal permeability coefficient is mainly divided according to the comprehensive geological data of the study area, with the emphasis on the dominant hydrogeological characteristics, including metamorphic rock, sedimentary 
rock, sandy soil and sand gravel, clay and silt. The fault is divided into different permeability coefficients and reflected in the model, and the heterogeneous parameter model [9] is obtained. The consideration of heterogeneity is more in line with the actual hydrogeological conditions and can better reflect the groundwater flow in the area. The partition of vertical permeability coefficient is consistent with that of horizontal permeability coefficient partition as shown in Fig. 6.

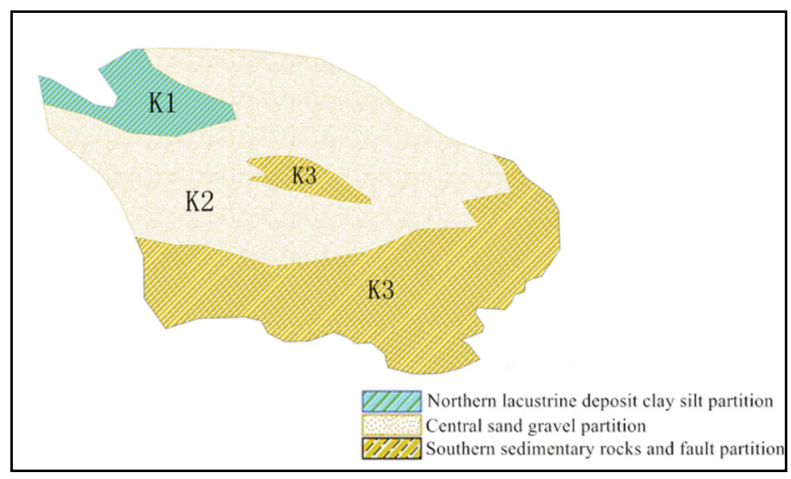

Fig. 6. Horizontal permeability coefficient partition map

Through the screening of borehole data, the preliminary pumping test and the analysis of hydrogeological conditions, as well as the reference to the empirical value of borehole lithology. The regional values of permeability coefficient of model hydrogeological parameters are shown in Table 2 . According to the geological conditions and empirical values of the study area, the ratio of vertical permeability coefficient to horizontal permeability coefficient is 0.25 in the model, and the trial calculation is carried out in the model.

Table 2. Model permeability coefficient partition value

\begin{tabular}{|c|c|c|}
\hline \multirow{2}{*}{ Parameter partition } & \multicolumn{2}{|c|}{ Permeability coefficient(m/d) } \\
\cline { 2 - 3 } & $\begin{array}{c}\text { The upper } \\
\text { layer }\end{array}$ & $\begin{array}{c}\text { The lower } \\
\text { level }\end{array}$ \\
\hline $\begin{array}{c}\text { Northern lacustrine deposit } \\
\text { clay silt partition(K1) }\end{array}$ & 0.05 & 0.05 \\
\hline $\begin{array}{c}\text { Central sand gravel } \\
\text { partition(K2) }\end{array}$ & 3 & 3 \\
\hline $\begin{array}{c}\text { Southern sedimentary rocks } \\
\text { and fault partition(K3) }\end{array}$ & 0.2 & 0.15 \\
\hline
\end{tabular}

In the model, the ratio of the vertical permeability coefficient to the horizontal permeability coefficient is 0.25 , and the trial calculation is performed in the model.

\section{Groundwater numerical model}

\subsection{Mathematical model}

The input and output of groundwater system in the simulated area remain relatively stable, and the movement of groundwater can be generalized as a threedimensional steady flow [10]. The variation of parameters with space reflects the heterogeneity of groundwater system and has no obvious directionality. Combined with the generalization of the above structures, the groundwater flow in the simulated area can be generalized into heterogeneous isotropy, two-layer structure and stable groundwater flow system, which can be described by the following definite solutions of differential equation:

$$
\begin{aligned}
& k \frac{\partial}{\partial x}\left(h_{1} \frac{\partial h_{1}}{\partial x}\right)+k \frac{\partial}{\partial y}\left(h_{1} \frac{\partial h_{1}}{\partial y}\right)+W_{1}(x, y, t)=\mu \frac{\partial\left(h_{1}\right)}{\partial t}\left(x, y \in \Gamma_{0} ; t>t_{0}\right) \\
& \quad h_{1}\left|(x, y, t)=h_{1}^{0}\right|(x, y) \\
& \left(x, y \in \Omega_{1} ; t=0\right)(2) \\
& \left.k\left(h_{1}-d\right) \frac{\partial h_{1}}{\partial n}\right|_{(x, y, t)}=-q(x, y, t) \quad\left(x, y \in \Gamma_{1} ; t>t_{0}\right)
\end{aligned}
$$

$\Omega$-Seepage area;

$\mu$-Specific yield of water-bearing media;

k-Permeability coefficient of water-bearing media;

$\mathrm{h}$-The water level elevation of the aquifer (m);

h10-Initial water level $(\mathrm{m})$ of aquifer $(\mathrm{m})$;

$\mathrm{W} 1(\mathrm{x}, \mathrm{y}, \mathrm{t})$-Evaporation and rainfall $(\mathrm{m} / \mathrm{d})$ at the phreatic surface $(\mathrm{m} / \mathrm{d})$;

$\Gamma 1-L a t e r a l$ and lower boundaries of seepage area;

$\mathrm{Q}-\Gamma 1$ the flow of the boundary, the inflow is positive, the outflow is negative, and the water barrier boundary is $0(\mathrm{~m} / \mathrm{d})$;

$\Gamma 0$-The upper boundary of seepage area, that is, the free surface of groundwater;

$\Omega 1$-Seepage area;

\subsection{Establishment of numerical model}

The model is established by the combination of MODFLOW module and MAP module in GMS. In the model, rectangular meshes are used, and overall $1000 \mathrm{~m} * 1000 \mathrm{~m}$ mesh is used, which is divided into 97 columns and 60 rows, vertical and upward divided into two layers. The total number of cells is 11640 . Use grid encryption at the well location. Using Layer module under MAP to deal with hydrogeological parameter partition, and Recharge module under MAP module to deal with groundwater recharge and displacement, a numerical model of study area is established in GMS.

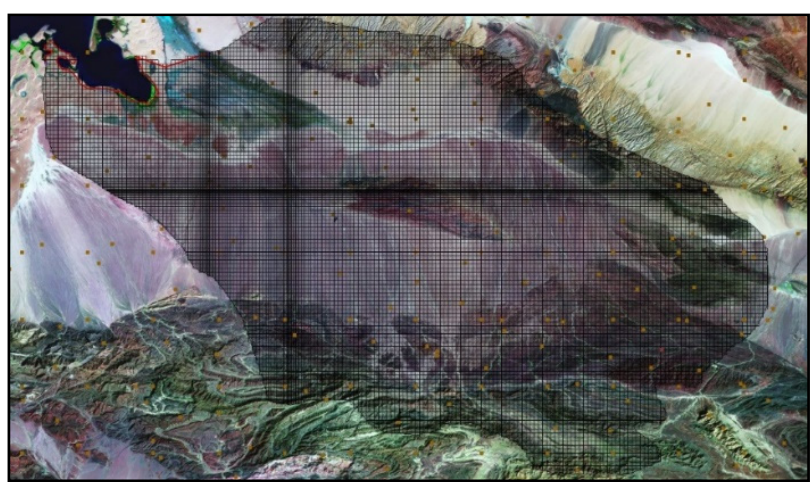

Fig. 7. Simulation area meshing

In order to determine the initial flow field of groundwater and other water level lines in the simulated area, the hydrogeological survey results of 1970s 
(borehole data) are adopted. Although the borehole does not fully reflect the groundwater level in the study area, it is analyzed by topography and geomorphology, stratigraphic structure, etc. There are some similarities and symmetries between groundwater flow field and geomorphology, so the map of groundwater flow field in the study area can be obtained by analogy.

Due to the uneven distribution of boreholes, the determination of local elevation is still determined by analogy method, and the local topographic profile is also an important basis for determining the elevation of each layer. Due to the uneven distribution of boreholes, the determination of local elevation is still determined by analogy method, and the local topographic profile is also an important basis for determining the elevation of each layer. According to the regional hydrogeological report, the average thickness of the Quaternary system is more than $300 \mathrm{~m}$, and this data will be given the elevation of the bottom plate of confined water. In addition to borehole data each layer is determined according to the characteristics of surface undulation and when the model is debugged the height of the aquifer is adjusted appropriately to characterize the aquifer. After determining the initial flow field, initial recharge discharge conditions and parameters, MODFLOW can be run to simulate. The result of the simulation is displayed directly in the display window in the form of the groundwater level isoline.

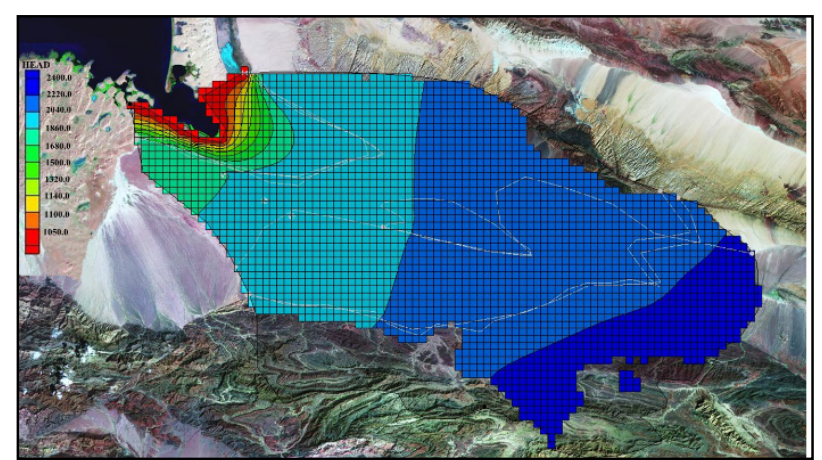

Fig. 8. Calculate the head value in the simulation area

\subsection{Model identification and verification}

Model checking is an important part of groundwater numerical simulation. By comparing the operation results with the required flow field, the parameters are modified until the required parameters are obtained [11]. In addition to comparing the calculated flow field with the measured flow field, the model should be verified by introducing the observation hole and comparing the calculated results with the simulation results. The verification method of GMS is used. After the observation hole is introduced, the observation results are shown in Fig. 9:

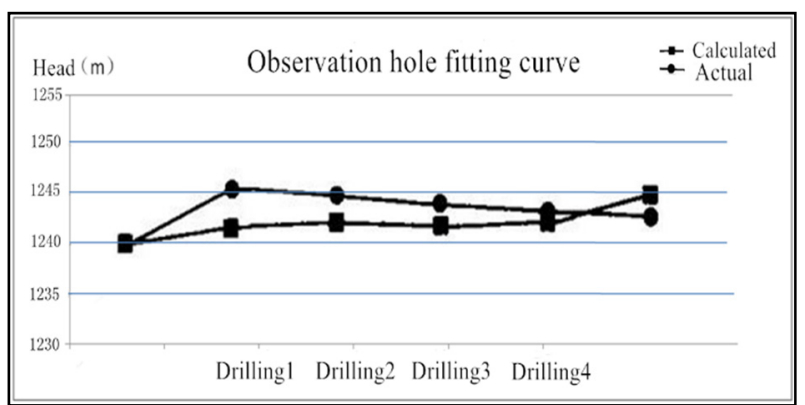

Fig. 9. Observation hole hydrological fitting

The fitting error between the calculated value of groundwater level of aquifer and the measured value of the number of observation wells is less than $5 \mathrm{~m}$ during the period of identification and verification. The results of identification and verification show that the concept of hydrogeology is correct. At the same time it also shows that the model can correctly reflect the hydrogeological conditions in the study area.

\section{Evaluation of groundwater resources}

The output of MODFLOW operation results is in a text file, and the output of the model is the total amount of each source sink term, which needs to be restored according to the method used in the input of the model data, and the composition of groundwater resources in the simulated area is obtained by calculation.

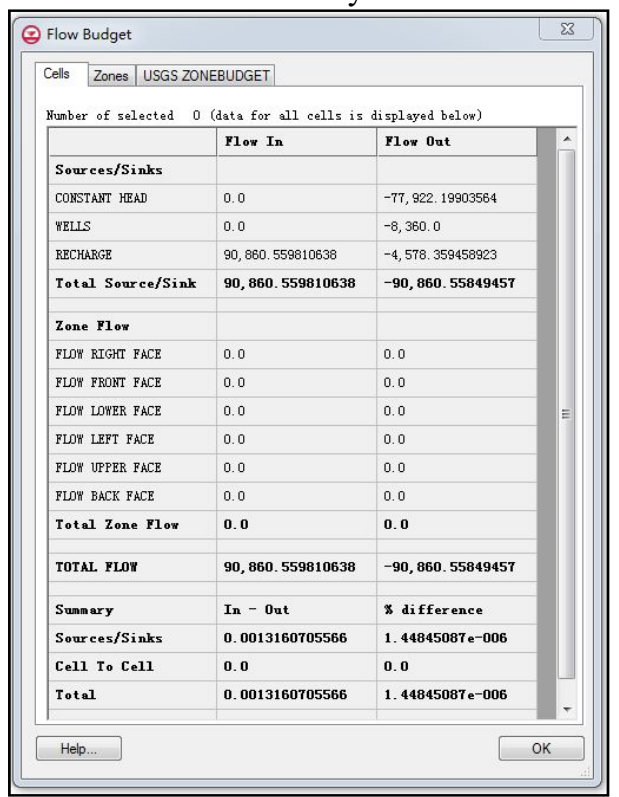

Fig. 10. Model water balance calculation result

It can be seen from the model that groundwater drains from mountainous area to Bosten Lake and flows from southeast to northwest. Recharge resources: by using the parameters corrected by the numerical model, according to the average precipitation and the leakage of the flood current, according to the calculation results of the water balance in Fig. 9, the rainfall infiltration recharge in the studied area is 33.164 million $\mathrm{m}^{3} / \mathrm{a}$. Excretion: the artificial extraction is about 3.149 million $\mathrm{m}^{3} / \mathrm{a}$, the natural evaporation is 1.671 million $\mathrm{m}^{3} / \mathrm{a}$, and the northern discharge to Bosten Lake is 28.442 million $\mathrm{m}^{3} / \mathrm{a}$. The average recharge of the aquifer is 
approximately equal to the average excretion and is in a steady state.

The recharge in this simulation is known as aquifer precipitation recharge. Although there are some deficiencies in local details and data accuracy, the model preliminarily depicts the characteristics of groundwater flow in the region as a whole. It does not affect the analysis of groundwater flow characteristics from a regional perspective, and can provide support for the analysis of regional groundwater circulation. From the point of view of water balance, the model is basically in line with the actual situation. In summary, the simulated flow field map can clearly reflect the distribution law of ground water in the study area, and the error from the actual observation value is smaller, and the model setting is more reasonable.

The quantity of recoverable groundwater resources refers to the guaranteed quantity of groundwater resources under the condition of reasonable economic and technological conditions, no deterioration of water quality or other bad geological phenomena, and no impact on the environment during the exploitation process [12]. In this calculation, the amount of natural groundwater recharge in the simulated area is about 33.164 million $\mathrm{m}^{3} / \mathrm{a}$, the annual natural evaporation of groundwater is about $1.671 \mathrm{million}^{3} / \mathrm{a}$, and the reserve natural discharge is about 31.493 million $\mathrm{m}^{3} / \mathrm{a}$. Therefore, the theoretical recoverable groundwater is about 22.045 million $\mathrm{m}^{3} / \mathrm{a}$. It can be seen from the discharge term that evaporation and sink to Bosten Lake are the main discharge modes of groundwater in the simulated area, and that the exploitation of fresh water and brackish water should be appropriately increased in the northern part of the simulated area. It can not only increase the utilization of water resources, but also reduce the groundwater level, and reduce the phreatic evaporation, especially in the vicinity of Bosten Lake, the proper lowering of the groundwater level is conducive to the improvement of saline-alkali land.

\section{Conclusion}

In this paper, a numerical model of groundwater on the southeast bank of Bosten Lake is established by using GMS software. Through the verification of the model, the reliability of the model is high. Finally, the total amount of groundwater resources and recoverable resources in this area are obtained by calculating the water balance of the model. Through the model analysis of groundwater resources, it can be known that groundwater exploitation mode can be changed. Groundwater resources are important fresh water resources in simulation area. In order to make rational use of groundwater resources, we should adjust the water supply structure in this area and increase the use of water-saving equipment for agricultural water in order to improve the utilization efficiency of water resources. Due to the larger area of the study area, there is a lack of long-term groundwater monitoring data in the course of the simulation prediction. In order to monitor groundwater dynamics more conveniently, the monitoring site layout and data collection should be strengthened.

\section{References}

1. Xue Y.Q, Xie C.H, Groundwater numerical simulation(Science Press,2007).

2. Zhang Z.K, Li L.R, China Groundwater Resources( Geological Press,2012).

3. Zhou X, Hu F.S, Introduction to Groundwater Science(Geological Press,2009).

4. Nastex. M, Rivera. A, Lefebvre. R, et al, Numerical smrulation of goundwater flow in regional rock aquifer southwextem Quebec Canada. Hydrogeology Joumal,13(5-6):835-848(2005).

5. Panday .S, Langevin .C.D, Improving sub-grid scale accunacy of boundary features in regional finitedifference models. Advances in Water Resources,41:65-75(2012).

6. Pang .Z.H, Huang .T.M, Chen .Y.N, Diminished Groundwater Recharge and Circulation Relative to Degrading Riparian Vegetation in Middle Tarim River, Xinjiang Uygur, Westem China. Hydrological Process, 2:147-159(2010).

7. Camrol .R.W.H, Pohll .G.M, Hershey .R.L, An unconfined groundwater model of the Death Vally Regional Fow System and a companison to its confined predecessor. Jounal of Hydrology,373(34):316-328(2009)..

8. Zghibi .A, Zouhn .L, Tarhouni .J, et al, Groundwater mineralization processes in Mediterranean semi-arid systens : Hydrogeological and geocherical approaches.Hydrological Processes,27(22):32273239(2013).

9. Camrol R WH,Pohll G M,Hershey RL,2009.An uncon fined groundwater model ofthe Death Vally Regional Fow. System anda companison to its con fined pre decessor,Jounal of Hydrology,373(34):316-328.

10. Xue Y.Q. Present Situation and Prospect of Groundwater Numerical Simulation in China[J]. Geological Journal of China Universities , 16(1):16(2010).

11. Wang .H, Lu .C, Qin .D, et al. Advances in method and application of groundwater numerical simulation[J]. Earth Science Frontiers, 17(6):112(2010).

12. Qiang .W.U, Zhu .B, Hua .X.U, et al. Application of MODFLOW in groundwater numerical simulation in Huaibei city[J]. Journal of Liaoning Technical University(2005). 